\title{
BENEFICIAL BACTERIA ISOLATED FROM MANGROVES IN THE TIGER SHRIMP CULTURE
}

\author{
Masilamani Selvam ${ }^{1}$ \& Kandasamy Kathiresan ${ }^{2 *}$ \\ ${ }^{1}$ Department of Biotechnology, Sathyabama University, Chennai, India \\ ${ }^{2}$ Centre of Advanced Study in Marine Biology, Annamalai University, Parangipettai, Tamilnadu, India \\ E-mail: masilamaniselvam@gmail.com
}

\section{ABSTRACT}

The potential effect of two beneficial bacteria - Azotobacter vinelandii and Bacillus megaterium - was studied in experimental tanks cultured with Penaeus monodon. The shrimps exhibited higher levels of production and growth rate, along with lower levels of food consumption and food conversion ratio, in the experimental tanks inoculated with the bacterial strains. There was also a significant reduction in the level of ammonia. All these beneficial effects were higher in the tanks treated with $B$. megaterium than $A$. vinelandii and mixed cultures.

KEY WORDS: Probiotic bacteria, Bacillus megaterium, Azotobacter vinelandii, Penaeus monodon, water quality, shrimp

\section{INTRODUCTION}

Outbreaks of the white spot disease have done considerable damage to the development of shrimp industry. The disease outbreak and production losses have been linked to deteriorating water quality (11). The brackishwater, which is used for the cultures, has low levels of nitrogen and phosphorus (12). Therefore, to improve water quality, nitrogen and phosphate fertilizers are supplemented for the aquaculture practices, either in the form of chemical fertilizers or 'probiotics'. The probiotics are live microbial feed supplements, increasingly used for environment-friendly aquaculture. In the way of applying through water, they act beneficially in improving the water quality, increasing growth of the shrimps and making the animals healthy and active (3). The probiotics mostly include vibrios, pseudomonads, lactic acid bacteria, bacilli and yeasts. However, nitrogen-fixing azotobacters are not used in the probiotics. It is also not clear about the source of beneficial microbes used in the preparation of commercial probiotics. In the present study, strains of Azotobacter vinelandii (nitrogen fixer) and Bacillus megaterium (phosphate solubilizer) were tested for their effect on water quality and growth of the tiger shrimp in culture tank conditions.

\section{MATERIALS AND METHODS}

\section{A. Shrimp and rearing condition}

Juveniles of the tiger shrimp Penaeus monodon Fabricius each weighing 0.70 ü0.05 $\mathrm{g}$ were collected from the Vellar estuary, Parangipettai (Lat. $11 \cdot 29^{\prime} \mathrm{N}$; Long.79.46'E). The juveniles were visually sorted out for their healthy and active conditions and were stocked in plastic tanks (40 L) for three days for acclimatization to laboratory conditions. Ten animals were used for each treatment in filtered seawater with aeration. For each treatment, triplicates were maintained prior to stocking. Juveniles were measured for total length and weight. The experiment was conducted for 15 days in the plastic tank containing 35-Litre of filtered estuarine water, collected from the estuary. Aeration was provided using air-stones. Salinity was maintained between 25 and $35 \mathrm{~g} \mathrm{~L}^{-1}$.

\section{B. Experimental design}

The cultures of Azotobacter vinelandii and Bacillus megaterium with the density of $10^{9}$ cells per $\mathrm{mL}$ were inoculated into the tank with the 20 Litres of seawater and aerated for $5 \mathrm{~h}$. The microbial cultures were used individually and in combination. Then the culture inoculum with the cell density of $10^{6}$ per $\mathrm{mL}$ was splashed over the experimental tanks. The inoculation was made two times per day, on the first, fifth and tenth days of culture. In control tanks, no microbial inoculation was made. Water exchange was made for $30 \%$ of the culture water every morning. Commercial pellet feed (CP-Grower B) was given at a rate of $9 \%$ of the body weight, twice a day $-50 \%$ at dawn $(6.00$ a.m.) and $50 \%$ at dusk (6.00 p.m.).

Before feeding and water exchange, the unutilized feed and faecal matter were collected separately by siphoning out the water using $2-\mathrm{cm}$ dia. plastic hose. The collected unutilized feed and faecal matter were placed separately on a pre-weighed Whatman No.1 filter paper, cleaned with distilled water, dried in an oven at $60^{\circ} \mathrm{C}$ for $24-$ $h$ and then weighed.

\section{Water quality analysis}

Water quality was analysed in terms of temperature by using a Celsius thermometer, salinity after exchange of water by using a hand refractometer (ATAGO, S/m11, Japan), $\mathrm{pH}$ using a $\mathrm{pH}$ meter (Hanna Instruments, Portugal), dissolved oxygen (Yellow Springs Instrument, USA), nutrients such as ammonia, nitrite, nitrate (14) and total phosphate (8) using the standard procedures.

\section{Shrimp growth analysis}

Total length was measured and fresh weight was weighed in live condition of the animal. Moulting was 
observed on the fourth and fifth day of culture in all the tank animals. Survival rate was calculated as $95 \%$. From the data collected, the food consumed, mean weight, production, assimilation, metabolism, growth rate, average daily growth, assimilation efficiency, gross conversion efficiency, net conversion efficiency, consumption efficiency, relative growth rate, feed conversion ratio (FCR) and food co-efficient were calculated (1).

\section{E. Statistical analysis}

One-way and two-way ANOVA were applied to determine the significance of measurements for the water quality as well as shrimp growth parameters.

\section{RESULTS}

\section{A. Water quality}

Water quality parameters recorded in the tanks treated with Azotobacter vinelandii and Bacillus megaterium, singly or in combination, along with control are given in Table- 1 . The average temperature varied significantly between $28 \cdot \mathrm{C}$ in all the treated tanks and $29 \cdot \mathrm{C}$ in control. The treated tanks had lower temperature by $3.45 \%$ than the control tank. The DO level varied between $4.5 \mathrm{mg} \mathrm{L}^{-1}$ in azotobacter-treated and bacillus-treated and $4.7 \mathrm{mg} \mathrm{L}^{-1}$ in control and mixed culture. The $\mathrm{pH}$ ranged from 7.7 in azotobacter and mixed cultures to 7.8 in control and bacillus treated tanks. However, there was no significant difference in $\mathrm{DO}$ and $\mathrm{pH}$ noticed between the control and experimental tanks.

The level of ammonia was significantly lower in experimental tanks than that in the control tank (Table- 1). The reduction of ammonia level was $77.08 \%$ in bacillustreated tank and $43.75 \%$ in mixed culture and $21.7 \%$ in azotobacter-treated tank. Fig shows that the level of ammonia increased from 1.5 to $7.6 \mathrm{\mu g} \mathrm{L}^{-1}$ in control tank. However, in the experimental tanks, the level of ammonia was significantly lower than that in the control tank. In bacillus-treated tank, the level of ammonia was maintained at very low level throughout the days of culture.

The average levels of nitrite fluctuated from $11.58 \mu \mathrm{g}$ $\mathrm{L}^{-1}$ in bacillus-treated tank to $13.12 \mathrm{Mg} \mathrm{L}^{-1}$ in mixed culture. The average levels of nitrate varied from $29.14 \mathrm{Mg} \mathrm{L}^{-1}$ in azotobacter-treated to $39.89 \mathrm{\mu g} \mathrm{L}^{-1}$ in bacillus-treated. The average levels of phosphate ranged from $21.7 \mathrm{Mg} \mathrm{L}^{-1}$ in control to $29.13 \mathrm{\mu g} \mathrm{L}^{-1}$ in bacillus-treated (Table- 1). However, none of the above-said values between the treatments are significant.
Table 1. Water quality parameters in culture tanks treated with microbial strains

\begin{tabular}{|c|c|c|c|c|c|}
\hline \multirow[t]{2}{*}{ Variable } & \multicolumn{4}{|c|}{$\begin{array}{l}\text { Average value of } 15 \text { days culture } \\
\qquad \text { (Mean } \pm \text { SE) }\end{array}$} & \multirow{2}{*}{$\begin{array}{l}\text { Variance } \\
\text { ratio and } \\
\text { levels of } \\
\text { significanc } \\
\text { e between } \\
\text { treatments }\end{array}$} \\
\hline & $\begin{array}{l}\text { Contr } \\
\text { ol }\end{array}$ & $\begin{array}{c}\text { A. } \\
\text { vinelan } \\
\text { dii }\end{array}$ & $\begin{array}{l}\text { B.megat } \\
\text { erium }\end{array}$ & $\begin{array}{l}\text { Mixed } \\
\text { culture }\end{array}$ & \\
\hline Temp $\left({ }^{\circ} \mathrm{C}\right)$ & $\begin{array}{c}29 \ddot{0} 0 . \\
2\end{array}$ & $\begin{array}{l}28 u ̈ .02 \\
(3.45)\end{array}$ & $\begin{array}{l}28 u ̈ 0.2 \\
(3.45)\end{array}$ & $\begin{array}{l}28 u ̈ 0.2 \\
(3.45)\end{array}$ & $23.64^{\star *}$ \\
\hline $\begin{array}{l}\text { DO* (mg L- } \\
\text { 1) }\end{array}$ & $\begin{array}{c}4.7 u ̈ 0 . \\
3\end{array}$ & 4.5ü0.3 & 4.5ü0.2 & $\begin{array}{c}4.7 \ddot{0} 0 . \\
3\end{array}$ & $0.93 \mathrm{NS}$ \\
\hline $\mathrm{pH}$ & $\begin{array}{c}7.8 u ̈ 0 . \\
09\end{array}$ & $\begin{array}{c}7.7 \text { ü0.0 } \\
8\end{array}$ & 7.8ü0.07 & $\begin{array}{c}7.7 u ̈ 0 . \\
08\end{array}$ & $0.96 \mathrm{NS}$ \\
\hline $\begin{array}{l}\text { Ammonia } \\
\left(\mu \mathrm{L} \mathrm{L}^{-1}\right)\end{array}$ & $\begin{array}{c}4.8 u ̈ 0 . \\
9\end{array}$ & $\begin{array}{c}3.4 \ddot{0} 0.0 \\
4 \\
(21.7)\end{array}$ & $\begin{array}{l}1.1 u ̈ 0.1 \\
(77.08)\end{array}$ & $\begin{array}{c}2.7 u ̈ 0 . \\
3 \\
(43.75)\end{array}$ & $1469.40^{* *}$ \\
\hline $\begin{array}{l}\text { Nitrite ( } \mu \mathrm{g} \\
\left.\mathrm{L}^{-1}\right)\end{array}$ & $\begin{array}{l}11.99 \\
\text { ü8.1 }\end{array}$ & $\begin{array}{c}12.05 u ̈ ~ \\
8.2\end{array}$ & $\begin{array}{c}11.58 u ̈ 8 . \\
3\end{array}$ & $\begin{array}{c}13.12 \mathrm{ü} \\
7.9\end{array}$ & $0.905 \mathrm{NS}$ \\
\hline $\begin{array}{l}\text { Nitrate }(\mu \mathrm{g} \\
\left.\mathrm{L}^{-1}\right)\end{array}$ & $\begin{array}{l}32.29 \\
\text { ü3.9 }\end{array}$ & $\begin{array}{c}29.14 \ddot{u} \\
5.0\end{array}$ & $\begin{array}{c}39.89 u ̈ 7 . \\
6\end{array}$ & $\begin{array}{c}33.02 \mathrm{u} \\
3.0\end{array}$ & 0.99 NS \\
\hline $\begin{array}{l}\text { Phosphate } \\
\left(\mu \mathrm{g} \mathrm{L}^{-1}\right)\end{array}$ & $\begin{array}{c}21.7 u ̈ \\
11.5\end{array}$ & $\begin{array}{c}22.83 u ̈ ~ \\
10.5\end{array}$ & $\begin{array}{c}29.13 u ̈ 1 \\
4.5\end{array}$ & $\begin{array}{c}24.93 u ̈ \\
11.1\end{array}$ & 2.64 NS \\
\hline
\end{tabular}

** - Significant at 1\% level; NS - Not significant; values in parenthesis indicate the percentage over control; * Dissolved oxygen

\section{B. Shrimp growth parameters}

The linear growth of shrimp was higher in the bacillustreated $\left(0.78 \mathrm{~mm}\right.$ day $\left.{ }^{-1}\right)$ than in control tank $\left(0.38 \mathrm{~mm}\right.$ day $\left.^{-1}\right)$. The shrimps treated with azotobacter and mixed culture showed the growth rate of 0.73 and $0.68 \mathrm{~mm}^{2}$ day $^{-1}$ respectively (Fig. 1). Growth (in terms of wet weight gain) was significantly higher in treated than in the control tanks (Fig. 2). 


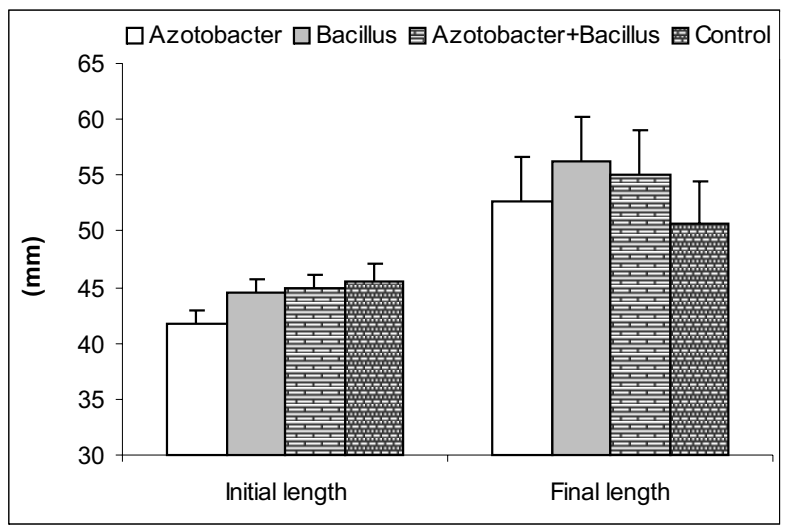

Fig. 1. Linear growth of Penaeus monodon fed for 15 days

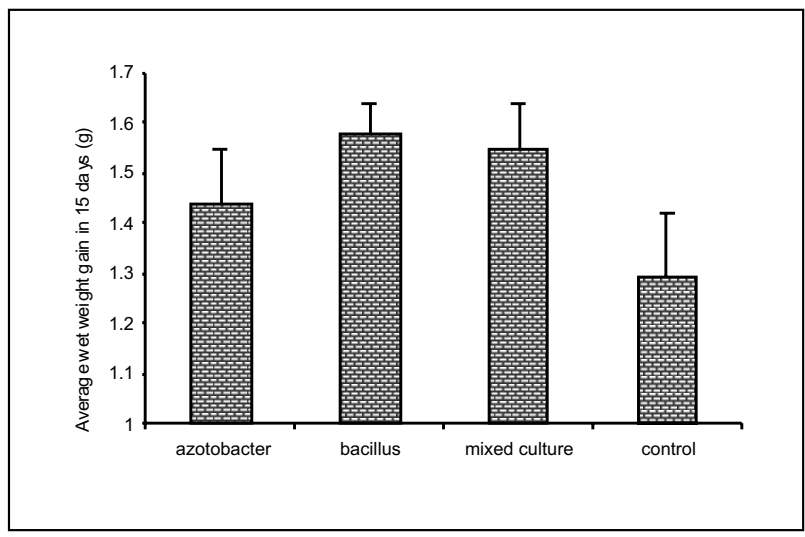

Fig. 2.Average wet weight gain in Penaeus monodon after 15 days of tank culture, under the influence of azotobacter, bacillus and mixed culture. values are average of 30 animals and with standard error.

The increment was $69.38 \%$ in bacillus-treated, $59.18 \%$ in mixed culture and $53.06 \%$ in azotobactertreated tanks, as compared to control. The shrimps showed high assimilation efficiency of $76.28 \%$ in bacillusinoculated tank followed by $73.37,70.93$ and $68.92 \%$ in control, mixed culture and azotobacter-inoculated tanks respectively (Table- 2). The gross conversion efficiency in the shrimps were 53.21, 50.68, 45.35 and $28.99 \%$ respectively in the tanks treated with bacillus, azotobacter, mixed culture and control. The net conversion efficiency ranged between $39.52 \%$ in control and $73.53 \%$ in azotobacter-treated. The highest value of consumption efficiency in shrimps was recorded as 24.14 in the control tank, followed by mixed cultures, azotobacter, and bacillusinoculated tanks with the values of 22.24, 20.75 and 20.00 respectively. The maximum food coefficient value was 3.45 recorded in animals of the control tank, followed by the values of 2.21, 1.97 and 1.88 in animals of mixed culture, azotobacter and bacillus-treated tanks respectively. The feed conversion ratio (FCR) was lower in treated tanks than in control tanks. The FCR varied from 1.57 in bacillustreated tank to 2.87 in control. Low FCR of 1.64 was also recorded in azotobacter-treated and 1.84 in mixed culture tank (Table-2).

Table 2. Budget giving weight gain of Penaeus monodon after 15 days culture treated with Azotobacter vinelandii, Bacillus megaterium individually and in combination

\begin{tabular}{|l|c|c|c|c|}
\hline $\begin{array}{l}\text { Growth } \\
\text { Measureme } \\
\text { nts* }\end{array}$ & $\begin{array}{l}\text { A.vin } \\
\text { eland } \\
\text { ii }\end{array}$ & $\begin{array}{l}\text { B. } \\
\text { megateri } \\
\text { um }\end{array}$ & $\begin{array}{l}\text { Mixe } \\
\text { d } \\
\text { cultur } \\
\text { e }\end{array}$ & Control \\
\hline $\begin{array}{l}\text { Initial } \\
\text { weight } \\
\text { (g) }\end{array}$ & 0.69 & 0.75 & 0.77 & 0.80 \\
\hline $\begin{array}{l}\text { Final weight } \\
\text { (g) }\end{array}$ & 1.44 & 1.58 & 1.55 & 1.29 \\
\hline $\begin{array}{l}\text { Weighed } \\
\text { mean (g) }\end{array}$ & 1.07 & 1.17 & 1.16 & 1.05 \\
\hline $\begin{array}{l}\text { Production } \\
\text { (g) }\end{array}$ & 0.75 & 0.83 & 0.78 & 0.49 \\
\hline $\begin{array}{l}\text { Food } \\
\text { consumed } \\
\text { (g) }\end{array}$ & 1.48 & 1.56 & 1.72 & 1.69 \\
\hline $\begin{array}{l}\text { Faecal } \\
\text { output (g) }\end{array}$ & 0.46 & 0.37 & 0.50 & 0.45 \\
\hline $\begin{array}{l}\text { Assimilatio } \\
\mathbf{n}\end{array}$ & 1.02 & 1.19 & 1.22 & 1.24 \\
\hline Metabolism & 0.27 & 0.36 & 0.44 & 0.75 \\
\hline $\begin{array}{l}\text { Assimilatio } \\
\text { n efficiency } \\
\text { (\%) }\end{array}$ & 68.92 & 76.28 & 70.93 & 73.37 \\
\hline $\begin{array}{l}\text { Gross } \\
\text { conversion } \\
\text { efficiency } \\
\text { (\%) }\end{array}$ & 50.68 & 53.21 & 45.35 & 28.99 \\
\hline $\begin{array}{l}\text { Net } \\
\text { conversion } \\
\text { efficiency } \\
\text { (\%) }\end{array}$ & 73.53 & 69.75 & 63.93 & 39.52 \\
\hline $\begin{array}{l}\text { Consumpti } \\
\text { on } \\
\text { efficiency }\end{array}$ & 20.75 & 20.00 & 22.24 & 24.14 \\
\hline FCR** & 1.64 & 1.57 & 1.84 & 2.87 \\
\hline $\begin{array}{l}\text { Food co- } \\
\text { efficient }\end{array}$ & 1.97 & 1.88 & 2.21 & 3.45 \\
\hline $\begin{array}{l}\text { Relative } \\
\text { growth rate } \\
\text { (\%) }\end{array}$ & 70.09 & 70.94 & 67.24 & 46.24 \\
\hline Growth rate & 10.51 & 10.64 & 10.09 & 7.00 \\
\hline
\end{tabular}

${ }^{*}$ After Crisp (1971); ** Feed conversion ratio Values are average of thirty animals 


\section{DISCUSSION}

In the present work, two bacterial strains isolated from mangrove sediment have been studied for their effects on water quality and growth of the tiger shrimp under tank culture conditions. The microbial inoculation has improved significantly the water quality parameters such as the levels of ammonia and water temperature (Table-1).

Ammonia is the main end product of protein catabolism in shrimps (5). The decay of organic matter also produces it. The exposure of shrimps to sub-lethal concentrations of ammonia increases susceptibility of the shrimps to diseases (15). In the present study, there is a build-up of ammonia in the control tanks with the days of culture. But in the experimental tanks, the ammonia is significantly at low levels during the course of experiment. This is because of the microbial activity of Bacillus megaterium and Azotobacter vinelandii used in the experimental tanks. This is in accordance with Porubcan (a) who has made a similar observation, when the tiger shrimp was cultured in water, pre-inoculated with nitrifying bacteria and bacillus. Of the microbial treatments, bacillus is effective in reducing the level of ammonia by $77.08 \%$. This may be due to the microbial activity in converting ammmonia into nitrate by nitrification through nitrite (Ravi et al. 1998), as is also evident by our data showing high level of nitrate $\left(39.89 \mu \mathrm{g} \mathrm{L}^{-1}\right.$; Table- 1$)$.

The present study reveals that the microbial treatment especially bacillus has increased the growth and biomass production, food conversion efficiency and reduced the consumption and feed conversion ratio in the tiger shrimp (Table-2). This can be attributed to the better water quality (Table- 1). Porubcan has also recorded that a microbial strain isolated from the tiger shrimp pond improves water quality, growth and production of Penaeus monodon. The beneficial effect is attributed to the efficiency of bacteria in (1) antagonism to pathogens (2) gut colonization, with possible adhesion to intestinal mucus, and to (3) increased resistance of the shrimps to pathogens (2\&3). Moriarty has noted an increase of prawn survival in the pond water inoculated with Bacillus spp. This is attributed to the water quality improved by the bacterial inoculation, as a result of degradation of organic matter. This treatment also has decreased the pathogenic luminous Vibrio spp. and other bacteria (6). This antagonistic activity of Bacillus species may be mediated not only by antibiotics, but also by many other inhibitory substances, such as organic acids, hydrogen peroxide (13) and siderophores (4). The strains of Bacillus are also known to compete for nutrients and for space for pathogenic bacteria. These mechanisms of Bacillus spp., may even prevent the emergence of resistant strains, a well-known risk of antibiotic treatments (7).
In this study, the bacterial strains especially Bacillus megaterium showed significant effect on the tiger shrimp culture tank, by enhancing the growth and production of shrimp through the reduction of ammonia.

\section{ACKNOWLEDGEMENT}

The authors are thankful to the Annamalai University for providing the facilities.

\section{REFERENCES}

[1] Crisp, P. I., 1971, Methods for the study of marine benthos, (ed. by H.A. Holme \& A.D. Mclntyre), pp. 197. Blackwell Scientific Publications Ltd, Oxford.

[2] Evelyn, T. P. T., 1996, Infection and disease. In: The Fish Immune System. Organisms, Pathogen and Environment (ed. by G. Iwama \& T. Nakanishi), pp. 115. Fish Physiol Series.

[3] Gate soupe, F. J., 1999, The se of probiotics in aquaculture. Aquaculture 180, 147-165.

[4] Gram, L. and Melchoirsen, J. 1996, Interaction between fish spoilage bacteria Psedomonas sp. And Shewanella putrefaciens I fish extracts and on fish tissue. J. Appl. Bacteriol. 80, 589-595.

[5] Hargreaves, J.A., 1998, Nitrogen biogeochemistry of aquaculture ponds. Aquaculture 166, 181-212.

[6] Maeda, M., Nagami, K., Kanematsu, M. and Hirayama, K. (1997) The concept of biological methods in aquaculture. Hydrobiologia 358, 285290.

[7] Moriarty, D.J.W., 1998, Control of luminous Vibrio sp. In penaeid aquaculture ponds. Aquaculture 164, 351-358.

[8] Murphy, J. and Riley, J.P., 1962, A modified single solution method for the determination of phosphate in natural waters. Anal. Chim. Acta. 27, 31-36.

[9] Porubcan, R. S., 1991a, Reduction of ammonia nitrogen and nitrite in tanks of Penaeus monodon using floating biofilter containing processed diatomaceous each media pre-inoculated with nitrifying bacteria. Program and Abstracts of the $22^{\text {nd }}$ Annual Conference and Exposition, World Aquaculture Society, San Juan Puerto Rico. 16-20 June. 
[10] Porubcan, R. S., 1991b, Reduction in chemical oxygen demand and improvement in Penaeus monodon yield in ponds inoculated with aerobic Bacillus bacteria. Program and Abstracts of the $22^{\text {nd }}$ Annual Conference and Exposition, World Aquaculture Society, Sari Juan, Puerto Rico, 16-20 June.

[11] Prabhu, N. M., Nazar, A. R., Rajagopal, S. and Ajmalkhan, S., 1999, Use of probiotics in water quality management during shrimp culture. J. Aqua. Trop. 14(3), 227-236.

[12] Ravi, V., Ajmalkhan, S. and Rajagopal, S., 1998, Influence of probiotics on growth of Indian white prawn Penaeus indicus. Journal of Scientific \& Industrial Research 57, 752-756.
[13] E. and Gatesoupe, F.J., 1998, Lactic and bacteria in fish: A review. Aquaculture 160, 177-203.

[14] Strickland, J.D.H. and Parsons, T.R., 1972, A practical handbook of seawater analysis. Fish.Res. Bd., Canada, pp. 167.

[15] Wajsbrot, N., Krom, M.D., Gasith, A. and Samocha, T., 1989 Ammonia excretion of green tiger prawn Penaeus semisulcatus as a possible limit on the biomass density in shrimp ponds. The Israeli Journal ofAquaculture-Bamidgeh 41(4), 159-164.

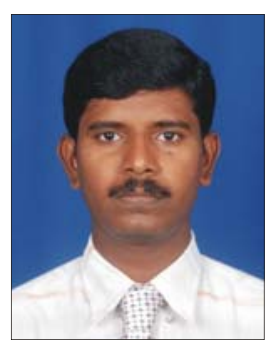

Dr. M. Masilamani Selvam is working as a Lecturer in the Department of Biotechnology, Sathyabama University and his field of specialization is Marine Biotechnology. 